\title{
The use of rhBMP in spine surgery: is there a cancer risk?
}

\author{
Authors John G DeVine ${ }^{1}$, Joseph R Dettori ${ }^{2}$, John C France ${ }^{3}$, Erika Brodt ${ }^{2}$, Robert A McGuire ${ }^{4}$ \\ Institutions ${ }^{1}$ Eisenhower Army Medical Center, Ft Gordon, GA, USA \\ ${ }^{2}$ Spectrum Research Inc, Tacoma, WA, USA \\ ${ }^{3}$ Department of Orthopaedics, West Virginia University, Morgantown, WV, USA \\ ${ }^{4}$ Department of Orthopaedic Surgery and Rehabilitation, University of Mississippi Medical Center, \\ Jackson, MS, USA
}

\section{ABSTRACT}

Study design: Systematic review.

Study rationale: Some have noted several safety issues associated with the use of bone morphogenetic proteins (BMPs), including cancer risk, stating both BMP and their receptors had been isolated from human tumors. In addition, data presented to the US Food and Drug Administration (FDA) on the product AMPLIFY Tм (rhBMP-2, $40 \mathrm{mg}$ ) revealed a higher number of cancers in the investigational group compared with the control.

Objective: To independently review the cancer risk of rhBMP-2 use in spine fusion as published in the peer-reviewed literature and in the publicly available FDA data summaries.

Methods: A systematic review of the literature was undertaken for articles published through January 2012. Pubmed, Cochrane, National Guideline Clearinghouse Databases as well as bibliographies of key articles were searched. Two independent reviewers revised articles. Inclusion and exclusion criteria were set and each article was subjected to a predefined quality-rating scheme.

Results: Five published peer-reviewed studies and two FDA safety summaries reported the occurrence of cancer in patients treated with spinal fusion using rhBMP-2 or rhBMP-7. Cancer data for on-label use of rhBMP-2 (InFUSE ${ }^{\mathrm{TM}}$ ) were reported in the FDA data summary but not in one published pivotal study. The risk of cancer was same in both the rhBMP-2 and control groups, $0.7 \%$ after 24 months. Off-label use of rhBMP for posterolateral fusion (PLF) was associated with a slightly higher risk of cancer compared with controls in three randomized controlled trials and one poorly conducted retrospective cohort study at various follow-ups. In PLF the risk of cancer was $3.8 \%$ using $40 \mathrm{mg}$ of BMP-2 compared with $0.9 \%$ in the control group. Two RCTs evaluating rhBMP-7 reported a cancer risk of $12.5 \%$ and $5.6 \%$ in the rhBMP-7 group compared with $8.3 \%$ and $0 \%$ in the control groups, respectively. The differences in these studies were not statistically significant; however, the sample sizes for these studies were small.

Conclusions: Cancer risk with BMP-2 may be dose dependent, illustrating the need to continue to study this technology and obtain longer follow-up on patients currently enrolled in the FDA trials. Additionally, refined guidelines regarding the routine use of BMPs should be developed, taking into account the FDA summary data that is not routinely scrutinized by the practicing surgeon.

This systematic review was funded by AOSpine. The authors declare no financial conflict of interest. 


\section{BACKGROUND}

Historically, spinal arthrodesis has relied on autogenous bone grafting to stimulate fusion. The autograft is typically obtained from either the anterior or posterior iliac crest, or when available, from locally harvested bone during a decompression. However, autograft is not always adequate in volume or quality, and can be associated with surgical morbidity. Accordingly, bone graft substitutes have been developed to enhance or replace traditional autograft. Recombinant human bone morphogenetic protein-2 (rhBMP-2), introduced commercially in 2002, has become one of the most commonly used bone graft substitutes. Currently, only rhBMP-2 and rhBMP-7 are clinically available. Use of rhBMP-7, also known as osteogenic protein 1 (OP-1), requires a humanitarian device exemption.

In a 2002 publication, Poynton and Lane [1] noted several safety issues associated with the use of BMPs, including cancer risk, noting both BMP and their receptors had been isolated from human tumors. However, they concluded that there was no evidence to date to suggest that BMPs were carcinogenic.

In a recent 2011 publication, Carragee et al [2] compared the conclusions regarding the safety and related efficacy of industry-sponsored trials of rhBMP-2 published in the peer-reviewed literature with data available from the US Food and Drug Administration's (FDA) data summaries. With respect to the product AMPLIFY TM (rhBMP-2, $40 \mathrm{mg}$ ), they [2] noted that though the risk of cancer was greater in the rhBMP-2 group compared with the control group, this point was underemphasized in the peerreviewed article. On the other hand, the FDA analysts were particularly concerned about this difference. The FDA, in response to the premarket approval application of AMPLIFY stated [3], "There is a concerning number of cancers in this study and all rhBMP-2 clinical spine studies. Recombinant BMP-2 has systemic effects, not unlike any other drug, and the medical community does not have enough information that relates to its long-term pharmacological effects." Furthermore, in support of the reasoning for its recommendation for post-market surveillance studies, the FDA stated, "Most importantly, there is a higher number of cancers in the investigational group as compared to the control group that warrants further investigation."

\section{OBJECTIVE}

To independently review the cancer risk of rhBMP-2 use in spine fusion as published in the peer-reviewed literature and in the publicly available FDA data summaries.

\section{MATERIALS AND METHODS}

Study design: Systematic review.

Search: PubMed, EMBASE, CINAHL, ClinicalTrials. gov, The Cochrane Library, The Agency for Healthcare Research and Quality, systematic reviews, primary studies and FDA reports, and bibliographies of key articles were searched for eligible studies that assessed the efficacy and safety of BMP in spinal fusion. Our search strategy was adapted from that of a comprehensive Health Technology Assessment evaluating on- and off-label uses of BMP for spinal fusion which we completed mid-January 2012.

Dates searched: Through January 15, 2012.

\section{Inclusion criteria:}

- Patients with back and/or leg or neck pain

- FDA-approved ("on-label") and -unapproved ("offlabel") implantation of rhBMP-2 or rhBMP-7 (OP-1) in the lumbar or cervical spine

- Comparators to include placebo, standard care, physical therapy, autograft bone, allograft bone, bone marrow, demineralized bone matrix, stem cells, and/or other bone substitutes used to enhance bone remodeling

- Studies that specifically mention cancer as an outcome that was evaluated

- Studies published in English-language peer-reviewed journals or publicly available FDA reports

\section{Exclusion criteria:}

- Skeletally immature patients ( $<18$ years of age)

- Pregnancy

- History of tumor in the implantation site

- Infection at the implantation site

- Implantation of the rhBMP-2 or rhBMP-7 into sites other than the spine

- Spine fusion not using rhBMP-2 or rhBMP-7

Outcomes: Incidence of any cancer.

Analysis: Descriptive statistics. Studies that did not mention cancer as a potential outcome were not included and therefore, not counted in the denominator. Trial heterogeneity prevented pooling. 


\section{RESULTS}

\section{Study types and demographics}

- Seven studies (five published peer-reviewed studies and two FDA safety summaries) were found that reported the occurrence of cancer in patients treated with spinal fusion using rhBMP-2 or rhBMP-7 (Fig 1). Four are randomized controlled trials (RCTs) comparing rhBMP with iliac crest bone graft (ICBG): two used off-label rhBMP-7 for posterolateral fusion (PLF) [4-7], one assessed off-label use of a higher dose rhBMP-2 for PLF $[3,8]$, and one reported on the on-label use of a lower dose rhBMP-2 for ALIF [9]. We identified 11 other RCTs and 24 comparative cohort studies that did not mention cancer. A list of these studies can be found in the Web appendix.

- Mean ages for the BMP and ICBG groups ranged from 43-63 and 42-67 years, respectively, across the RCTs with males comprising $45 \%-56 \%$ and $38 \%-50 \%$ of the respective populations. Mean follow-up times varied from 12-60 months (Table 1).

- One cohort study was also found comparing rhBMP-2 with ICBG for various surgical approaches[10]. Another study which conducted a review of the Medicare database to assess the risk for pancreatic cancer only was also included [11].

\section{Cancer risk}

- Cancer data for on-label use of rhBMP-2 (InFUSETM) were reported in the FDA data summary [9] but not in the published pivotal study by Burkus et al [12].
The risk of cancer was same in both the rhBMP-2 and control groups, $0.7 \%$ after 24 months.

- Off-label use of rhBMP for posterolateral fusion (PLF) was associated with a slightly higher risk of cancer compared with controls in three randomized controlled trials [3-8] and one poorly conducted retrospective cohort study [10] (Table 1).

- One RCT evaluated a high dose of rhBM-2 (40 mg, AMPLIFYTM) at 24 months follow-up. The results are published in a peer-reviewed journal [8] and in the FDA data summary [3]. With respect to cancer, there is a discrepancy in

Fig 1 Results of literature search.

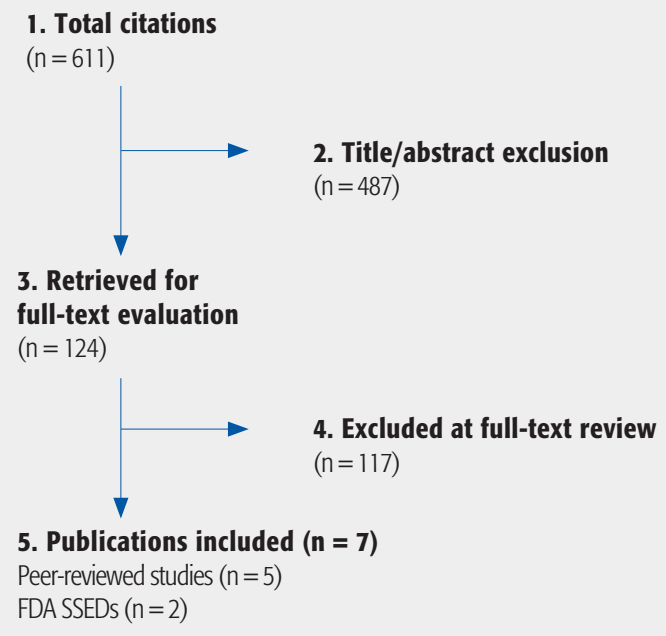

Table 1 Summary of cancer risks in studies of recombinant human bone morphogenetic protein-2 (rh-BMP).*

\begin{tabular}{|c|c|c|c|c|c|c|c|c|}
\hline & & & & Demographics & & Mean & Risk, \% (n) & \\
\hline Design & Surgery & Studies & Treatment & rhBMP & ICBG & follow-up, mo & rhBMP & Control \\
\hline \multirow[t]{4}{*}{ RCTs } & PLF & Vaccaro et al [5-7] & $\begin{array}{l}\text { rhBMP-7 } \\
(7 \mathrm{mg})\end{array}$ & $\begin{array}{l}\text { Age, y: } 63 \\
\% \text { Male: } 46\end{array}$ & $\begin{array}{l}67 \\
42\end{array}$ & 48 & $12.5(3 / 24)$ & $8.3(1 / 12)$ \\
\hline & PLF & $\begin{array}{l}\text { FDA [3] }(\text { AMPLIFY' } \\
\text { Dimar et al }[8]^{\dagger}\end{array}$ & $\begin{array}{l}\text { rhBMP-2 } \\
(40 \mathrm{mg})\end{array}$ & $\begin{array}{l}\text { Age, y: } 53 \\
\% \text { Male: } 45\end{array}$ & $\begin{array}{l}52 \\
42\end{array}$ & $\begin{array}{l}24 \\
60\end{array}$ & $\begin{array}{l}3.8(9 / 239) \\
6.3(15 / 239)\end{array}$ & $\begin{array}{l}0.9(2 / 224) \\
2.2(5 / 224)\end{array}$ \\
\hline & PLF & Delawi et al [4] & $\begin{array}{l}\text { rhBMP-7 (OP-1) } \\
\text { (3.5 mg/side) }\end{array}$ & $\begin{array}{l}\text { Age, y: } 53 \\
\% \text { Male: } 56\end{array}$ & $\begin{array}{l}55 \\
38\end{array}$ & 12 & $5.6(1 / 18)$ & $0(0 / 16)$ \\
\hline & ALIF & FDA [9] $]^{\ddagger}\left(\right.$ InFUSE $\left.{ }^{\mathrm{TM}}\right)$ & $\begin{array}{l}\text { rhBMP-2 } \\
\text { (mg NR) }\end{array}$ & $\begin{array}{l}\text { Age, y: } 43 \\
\% \text { Male: } 55\end{array}$ & $\begin{array}{l}42 \\
50\end{array}$ & 24 & $0.7(1 / 143)$ & $0.7(1 / 136)$ \\
\hline Cohort $\$$ & Mixedll & Latzman et al [10] & $\begin{array}{l}\text { rhBMP-2 }(12 \mathrm{mg} / 8 \mathrm{cc} \\
\text { or } 24 \mathrm{mg} / 16 \mathrm{cc})\end{array}$ & $\begin{array}{l}\text { Age, y: } 50 \\
\% \text { Male: } 78\end{array}$ & $\begin{array}{l}56 \\
90\end{array}$ & 18 & $16.7(4 / 24)$ & $7.6(8 / 105)$ \\
\hline
\end{tabular}

* ICBG indicates iliac crest bone graft; PLF, posterolateral fusion; ALIF, anterior lumbar interbody fusions; and NR, not reported.

t Dimar et al [8] is the randomized control trial (RCT) for the FDA data summary. The authors report only eight cases of cancer in the rhBMP group, while the SSED reports nine at 24-month follow-up.

$\ddagger$ Data from the pivotal RCT only. Results from the pilot RCT $(N=14)$ and the prospective case series $(N=134)$ submitted to FDA were not included in this analysis.

$\S$ Retrospective chart review.

II Anterior approach, 9\%; interbody cage placement, 44\%. 
the number of cases reported in the FDA summary $(n=9)$ versus the number in the journal article $(n=8)$. Using the FDA summary data, the risk of any cancer in the rhBMP-2 group was $3.8 \%$ compared with $0.9 \%$ in the controls, risk difference of $2.9 \%$ (95\% confidence interval [CI]: $0.2 \%-5.6 \%), P=.064$. In the FDA summary, 60 -month follow-up is reported with risks for rhBMP- $2=6.3 \%$ compared with $2.2 \%$ for controls. However, it is not clear how the calculations were determined given that the follow-up rate was less than $65 \%$ (65\% for rhBMP-2 group and $60 \%$ for the control group).

- Two RCTs evaluated rhBMP-7, one after 12 months and one after 48 months [4-7]. The cancer risk was $12.5 \%$ and $5.6 \%$ in the rhBMP-7 group compared with $8.3 \%$ and $0 \%$ in the control groups, respectively. The sample sizes in these studies were small and the differences were not statistically significant.

- The 2-year risk of cancer in the two studies that used different doses of rhBMP-2 is shown in Fig 2. The risk was similar in the lower dose (on-label) use of rhBMP-2 $(0.7 \%)$ and the control groups from each study, $0.7 \%$ and $0.9 \%$, while the risk in the higher-dose rhBMP-2 was $3.8 \%$.

- One study attempted to estimate the risk of pancreatic cancer after use of BMP with lumbar fusion using the Medicare and Medicare Part B claims data [11]. This study was conducted and funded by Wyeth Pharmaceuticals, a manufacturer of rhBMP-2. The authors reported a reduced risk of pancreatic cancer in the BMP group (adjusted hazard ratio $=0.70 ; 95 \%$ CI: $0.34-1.45$ ). Results from use of administrative databases are difficult to interpret. In general, administrative databases contain data that have been gathered as a by-product of some other process. The data may be collected and entered by hundreds of individuals at many locations; usually, there are few, if any, quality checks on the data; records may have different lengths and structures within the same database; and missing data are common $[13,14]$. One of the most obvious disadvantages is that these systems were not created for research purposes and, in most cases, researchers did not have input into the design or types of information collected by the systems. They may lack some of the details that researchers might want [15]. These characteristics of large databases lead to the controversy over their use in epidemiological and health services research and point to the need to consider validity and reliability issues [16, 17].

\section{Cancer types reported}

Cancer types were listed in all but one of the clinical trials (Table 2). The trial not listing cancer types evaluated rhBMP-7 (OP-1) [5-7]. Stryker Biotech, the owner of the OP-1, recently sold the orthopaedic rights to OP-1 to Japan's Olympus Corporation and is a defendant in a legal case surrounding the use and safety of the product (http:// ryortho.com/fda.php?news=1690_OP1-Trial-Starts-inBoston. Accessed January 26, 2012).

Fig 2 AP image intensifier showing the moment when the dye is injected into a L4-L5 disc discography.

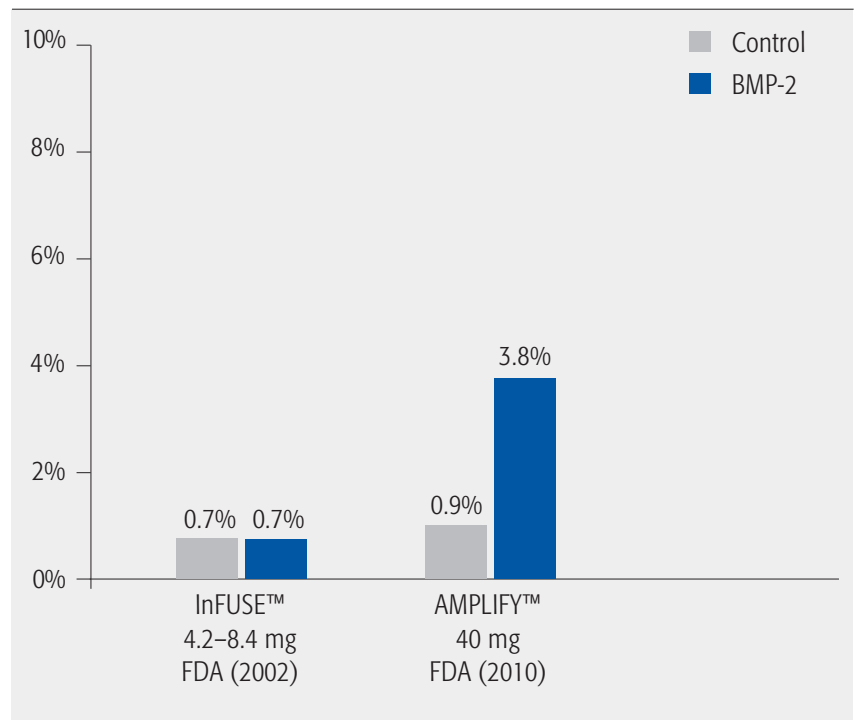


Table 2 Cancer types identified in studies of recombinant human bone morphogenetic protein (rhBMP).*

\begin{tabular}{|c|c|c|c|c|}
\hline & rhBMP & & Control & \\
\hline & Cancer type & No. $(\%)$ & Cancer type & No. $(\%)$ \\
\hline $\begin{array}{l}\text { Vaccaro et al [5-7] } \\
\text { BMP: } n=24 \\
\text { Control: } n=12\end{array}$ & $\begin{array}{l}\text { Specific cancers not reported } \\
\text { Total }\end{array}$ & $3(12.5)$ & $\begin{array}{l}\text { Specific cancers not reported } \\
\text { Total }\end{array}$ & $1(8.3)$ \\
\hline $\begin{array}{l}\text { Dimar et al [8] (FDA SSED AMPLIFY) } \\
\text { BMP: } n=239 \\
\text { Control: } n=224\end{array}$ & $\begin{array}{l}\leq 24 \text { mo } \\
\text { Laryngeal cancer } \\
\text { Lung cancer } \\
\text { Ovarian cancer } \\
\text { Pancreas cancer } \\
\text { Prostate cancers } \\
\text { Basal cell carcinomas } \\
\text { Squamous cell carcinomas } \\
\text { Total } \\
60 \text { mo (cumulative) } \\
\text { Laryngeal cancer } \\
\text { Lung cancer } \\
\text { Non-Hodgkin lymphoma } \\
\text { Ovarian cancer } \\
\text { Pancreas cancer } \\
\text { Prostate cancers } \\
\text { Stomach cancer } \\
\text { Thyroid cancer } \\
\text { Ocular cancer } \\
\text { Leukemia } \\
\text { Basal cell carcinomas } \\
\text { Squamous cell carcinomas } \\
\text { Total }\end{array}$ & $\begin{array}{l}1(0.4 \%) \\
1(0.4 \%) \\
1(0.4 \%) \\
1(0.4 \%) \\
1(0.4 \%) \\
2(0.8 \%) \\
2(0.8 \%) \\
9(3.8 \%) \\
1(0.4 \%) \\
1(0.4 \%) \\
1(0.4 \%) \\
1(0.4 \%) \\
1(0.4 \%) \\
2(0.8 \%) \\
1(0.4 \%) \\
1(0.4 \%) \\
1(0.4 \%) \\
1(0.4 \%) \\
2(0.8 \%) \\
2(0.8 \%) \\
2(0.8 \%) \\
15(6.3 \%)\end{array}$ & $\begin{array}{l}\leq 24 \text { mo } \\
\text { Non-Hodgkin lymphoma } \\
\text { Colon cancer } \\
\text { Total } \\
\\
60 \text { mo (cumulative) } \\
\text { Non-Hodgkin lymphoma } \\
\text { Colon cancer } \\
\text { Breast } \\
\text { Thyroid } \\
\text { Squamous cell carcinoma } \\
\text { Total }\end{array}$ & $\begin{array}{l}1(0.4 \%) \\
1(0.4 \%) \\
1(0.4 \%) \\
1(0.4 \%) \\
1(0.4 \%) \\
5(2.2 \%)\end{array}$ \\
\hline $\begin{array}{l}\text { Delawi et al [4] } \\
\text { BMP: } n=18 \\
\text { Control: } n=16\end{array}$ & $\begin{array}{l}\text { Brain cancer } \\
\text { (grade IV glioblastoma) } \\
\text { Total }\end{array}$ & $\begin{array}{l}1(5.6 \%) \\
1(5.6 \%)\end{array}$ & $\begin{array}{l}\text { None } \\
\text { Total }\end{array}$ & $\begin{array}{l}0(0.0 \%) \\
0(0.0 \%)\end{array}$ \\
\hline $\begin{array}{l}\text { FDA SSED [9] (InFUSE) } \\
\text { BMP: } n=143 \\
\text { Control: } n=136\end{array}$ & $\begin{array}{l}\text { Pancreatic cancer } \\
\text { Total }\end{array}$ & $\begin{array}{l}1(0.7) \\
1(0.7)\end{array}$ & $\begin{array}{l}\text { Breast cancer } \\
\text { Total }\end{array}$ & $\begin{array}{l}1(0.7) \\
1(0.7)\end{array}$ \\
\hline $\begin{array}{l}\text { Latzman et al [10] } \\
\text { BMP: } n=24 \\
\text { Control: } n=105\end{array}$ & $\begin{array}{l}\text { Prostate adenocarcinoma } \\
\text { Lung adenocarcinoma } \\
\text { Pancreatic adenocarcinoma } \\
\text { Rectal adenocarcinoma } \\
\text { Total }\end{array}$ & $\begin{array}{l}1(4.2 \%) \\
1(4.2 \%) \\
1(4.2 \%) \\
1(4.2 \%) \\
4(16.7 \%)\end{array}$ & $\begin{array}{l}\text { Basal cell carcinoma } \\
\text { Colon adenocarcinoma } \\
\text { Prostate adenocarcinoma } \\
\text { Lung adenocarcinoma } \\
\text { Bladder } \\
\text { Total }\end{array}$ & $\begin{array}{l}3(2.9 \%) \\
1(1.0 \%) \\
2(1.9 \%) \\
1(1.0 \%) \\
1(1.0 \%) \\
8(7.6 \%)\end{array}$ \\
\hline
\end{tabular}




\section{DISCUSSION}

- This review attempts to summarize the cancer risk from using rhBMP in spine surgery from the published peer-reviewed literature and available FDA summary data.

- The data review suggests that the cancer risk associated with BMP-2 may be dose dependent. This is based on the 2-year risk of cancer in the two studies that used different doses of rhBMP-2. The cancer risk was similar in the lower dose $(4.2-4.8 \mathrm{mg})$ of rhBMP-2 $(0.7 \%)$ and the control groups from each study $(0.7 \%$ and $0.9 \%)$. However, the cancer risk was $3.8 \%$ in the higher dose (40 mg) rhBMP-2 study.

- Thawani et al [18] reviewed basic science and clinical data to determine the role of BMP and cancer. Despite the large number of studies cited in this review reporting positive effects of BMP on cancer, they found no definitive association between BMPs and the promotion of tumorigenesis or metastasis.

- The appealing aspects of an available bone graft substitute, such as the BMPs cannot be overlooked, particularly in patients at high risk for pseudarthrosis. However, this fusion technology has experienced a rapid increase in utilization in all types of routine spine fusion procedures to include anterior cervical discectomy and fusions, posterolateral lumbar and cervical fusions, posterior and transforaminal lumbar interbody fusions, as well as anterior lumbar interbody fusions. Many of these procedures are multilevel. Cahill et al [19] noted that the nationwide usage of BMP increased from $0.69 \%$ of all fusions in 2002 to $24.89 \%$ of all fusions in 2006 , confirming the widespread application of this technology and its routine use in spinal fusion surgery.

- The alarming aspect of Cahill and colleagues' article [19] highlights the primary issue regarding any new technology that becomes commercially available and accepted into routine practice. There is little data available for analysis, particularly about the BMP dosing. Many of the patients received dosages well in excess of those studied in the FDA trials to date. Furthermore, the BMPs have been used in clinical practice beyond spinal fusion, and include treatment of extremity longbone nonunions and open fractures.

- In conclusion, review of available data suggests that cancer risk with BMP-2 may be dose dependent. This shows the need to further study this technology and obtain longer follow-up on patients currently enrolled in the FDA trials to analyze the long-term risks. In particular, a slightly elevated cancer risk was highlighted by the FDA and confirmed in this independent analy- sis versus the potential benefits. Additionally, refined guidelines regarding routine use of BMPs should be developed, taking into account the FDA summary data that is not routinely scrutinized by the practicing surgeon.

\section{REFERENCES}

1. Poynton AR, Lane JM (2002) Safety profile for the clinical use of bone morphogenetic proteins in the spine. Spine (Phila Pa 1976); 27(16 Suppl):S40-48.

2. Carragee EJ, Hurwitz EL, Weiner BK (2011) A critical review of recombinant human bone morphogenetic protein-2 trials in spinal surgery: emerging safety concerns and lessons learned. Spine J; 11(6):471-491.

3. Food and Drug Administration (FDA) (2010) Summary of Safety and Effectiveness Data (SSED) for P050036 Medtronic's AMPLIFY ${ }^{\mathrm{TM}}$ rhBMP-2 Matrix. Orthopaedic and Rehabilitation Devices Advisory Panel. Available at: http://www.fda.gov/downloads/advisorycommittees/committeesmeetingmaterials/ medicaldevices/medicaldevicesadvisorycommittee/orthopaedicandrehabilitationdevicespanel/ucm220079.pdf

4. Delawi D, Dhert WJ, Rillardon L, et al (2010) A prospective, randomized, controlled, multicenter study of osteogenic protein-1 in instrumented posterolateral fusions: report on safety and feasibility. Spine (Phila Pa 1976); 35(12):1185-1191.

5. Vaccaro AR, Anderson DG, Patel $T$, et al (2005) Comparison of OP-1 Putty (rhBMP-7) to iliac crest autograft for posterolateral lumbar arthrodesis: a minimum 2-year follow-up pilot study. Spine (Phila Pa 1976); 30(24):27092716.

6. Vaccaro AR, Patel T, Fischgrund J, et al (2004) A pilot study evaluating the safety and efficacy of OP-1 Putty (rhBMP-7) as a replacement for iliac crest autograft in posterolateral lumbar arthrodesis for degenerative spondylolisthesis. Spine (Phila Pa 1976); 29(17):1885-1892.

7. Vaccaro AR, Whang PG, Patel T, et al (2008) The safety and efficacy of OP-1 (rhBMP-7) as a replacement for iliac crest autograft for posterolateral lumbar arthrodesis: minimum 4-year follow-up of a pilot study. Spine J; 8(3):457-465.

8. Dimar JR 2nd, Glassman SD, Burkus JK, et al (2009) Clinical and radiographic analysis of an optimized rhBMP-2 formulation as an autograft replacement in posterolateral lumbar spine arthrodesis. J Bone Joint Surg Am; 91(16):1377-1386. 
9. Food and Drug Administration (2002) Summary of Safety and Effectiveness Data (SSED) for P000058 Medtronic's InFUSE ${ }^{\mathrm{TM}}$ Bone Graft/ LT-CAGE $^{\text {TM }}$ Lumbar Tapered Fusion Device. Orthopaedic and Rehabilitation Devices Advisory Panel. Available at: http://www.accessdata. fda.gov/cdrh_docs/pdf/P000058b.pdf

10. Latzman JM, Kong L, Liu C, et al (2010) Administration of human recombinant bone morphogenetic protein-2 for spine fusion may be associated with transient postoperative renal insufficiency. Spine (Phila Pa 1976); 35(7):E231-237.

11. Mines D, Gu Y, Kou TD, et al (2011) Recombinant human bone morphogenetic protein-2 and pancreatic cancer: a retrospective cohort study. Pharmacoepidemiol Drug Saf; 20(2):111-118.

12. Burkus JK, Gornet MF, Dickman CA, et al (2002) Anterior lumbar interbody fusion using rhBMP-2 with tapered interbody cages. J Spinal Disord Tech; 15(5):337-349.

13. Baron JA, Weiderpass E (2000) An introduction to epidemiological research with medical databases. Ann Epidemiol; 10(4):200-204.

14. Lange LL, Jacox A (1993) Using large data bases in nursing and health policy research. J Prof Nurs; 9(4):204-211.

15. Cowper DC, Hynes DM, Kubal JD, et al (1999) Using administrative databases for outcomes research: select examples from VA Health Services Research and Development. J Med Syst; 23(3):249-259.

16. Connell FA, Diehr P, Hart LG (1987) The use of large data bases in health care studies. Annu Rev Public Health; 8:51-74.

17. Flood AB (1990) Peaks and pits of using large data bases to measure quality of care. Int $J$ Technol Assess Health Care; 6(2):253-262.

18. Thawani JP, Wang AC, Than KD, et al (2010) Bone morphogenetic proteins and cancer: review of the literature. Neurosurgery; 66(2):233-246; discussion 246.

19. Cahill KS, Chi JH, Day A, et al (2009) Prevalence, complications, and hospital charges associated with use of bone-morphogenetic proteins in spinal fusion procedures. JAMA; 302(1):58-66.

\section{EDITORIAL PERSPECTIVE}

The authors deserve recognition for having performed, to date, the most exhaustive review on a possible association of BMP in spine surgery from an unbiased perspective (note the disclosures of the authors, AOSpine has no reportable financial conflict of interest). Their conclusions confirm the suspicion, voiced by Caragee et al, that there indeed may be a dose-dependent relatively modest increase of reported cancer cases in an rhBMP spine surgery population based upon currently available data [1].

Looking through the data tables, it appears that the listed cancer types are incidental in nature and not of the systemic or disseminated variants one might be most concerned about with a growth-enhancing substance, such as bone morphogenetic protein. Instead there is a wide distribution of isolated and more localized cancers reported in the rhBMP group, such as basal cell, squamous cell, prostate, laryngeal, and ocular cancers.

Such isolated cancer reports warrant further detailed assessment, such as subtle differences in the differences in each of the study groups - demographics, health status reporting, and follow-up $(65 \%$ in the rhBMP group and $60 \%$ in the control group).

No doubt the conclusion of having heightened awareness for adverse incidents with any new technologies as they enter mainstream practices is desirable but difficult to implement in reality. As DeVine et al point out, administrative claims databases unfortunately may not be suitable to detect occasional occurrences, such as cancers.

After reviewing the data at hand, AOSpine has asked DeVine et al to expand their search to encompass wider applications of $B M P$ in other organ systems and for other applications.

1. Carragee EJ, Hurwitz EL, Weiner BK (2011) A critical review of recombinant human bone morphogenetic protein-2 trials in spinal surgery: emerging safety concerns and lessons learned. Spine J; 11(6):471-491. 